\title{
Modern Islam in Translation: Reformist Aspirations and the Qur'an
}

\author{
Yunus Doğan Telliel*
}

M. Brett Wilson,

\section{Translating the Qur'an in an Age of Nationalism: Print Culture and Modern Islam in Turkey,}

Oxford: Oxford University Press, 2014, 352 pp., ISBN 978-019-8719-43-4.

In the early twentieth century, translating the Qur'an into local vernaculars was met with general reluctance and even open opposition among Muslims, yet today Qur'an translations abound in commercial markets around the world. How can we understand this shift? How is it that translations of the Qur'an have become so ubiquitous over the course of a century? Brett Wilson tackles these questions by tracing Muslim perceptions of, and ways of relating to the Qur'an from the mid-nineteenth century to the 1930s. Documenting cultural effects of both printing technology and nationalism in the Ottoman-Turkish context and beyond, Wilson argues that the Qur'an has been transformed from a scribal artifact into "a modern book which can be read in virtually any language" (p.2). This transformation, he shows, is manifested in the emergence of a new sense of access to the Qur'an, enabled by factors, such as increased affordability of Qur'an copies, individual ownership, and modern ideas of religiosity that favor 'unmediated' comprehension of the text. Wilson focuses primarily on debates and policies around printing and

* City University of New York - Graduate Center. 
translating the Qur'an in Turkey's late Ottoman and early Republican periods, but locates these alongside contemporaneous exchanges that were taking place across Egypt, India and Europe. The Ottoman-Turkish context appears especially pertinent to understanding the flourishing of Qur'an translations following World War I, as the question of translation often reflected the predicaments of the post-Caliphate world, from contested nationalisms and claims for Islamic leadership to the rise of English as a new medium of Islamic literature.

Drawing on Wilson's doctoral research at Duke University, Translating the Qur'an in an Age of Nationalism is located at the intersections of Islamic studies and Ottoman-Turkish history. Bridging these fields, Wilson provides a compelling narrative that brings together various intellectual figures (from İsmail Ferruh Efendi and Namık Kemal, to Rashid Rida and Muhammad Pickthall), theological debates (from Hanafi fiqh to ijaz al-quran) and historical processes (from the rise of print capitalism to the politics of Islamic reform). Wilson's book will be a welcome addition to the growing Western scholarship on the Qur'an. While these studies have often centered on the legal and political implications of Qur'anic hermeneutics, Wilson considers many less explored questions concerning the reproduction, circulation, and regulation of the Qur'anic text. He also joins the relatively few scholars ${ }^{1}$ who have devoted full attention to practices of Qur'anic translation and conceptions of religious language in modernity, which are often marginalized in sweeping histories of Muslim politics.

The first two of Translating the Qur'an's eight chapters focus on the question of printing the Qur'an in the nineteenth century. In chapter one, Wilson discusses how the introduction of print technology initiated the slow but steady move away from a scribal culture around the Qur'an. Although the Ottoman state initially disallowed printing of the Qur'an and the circulation of printed copies, Wilson shows that the incessant flow of 'black-market' copies (from Iran, India or Russia) continued unabated. Despite the initial reluctance toward printing the Qur'an, the printing of other religious texts had been considered by Ottoman reformers, beginning with Selim III, as part of broader Ottoman modernization. ${ }^{2}$ The first printed Islamic text, Risale-i Birgivi, a popular catechism by the sixteenth century

I E.g. Sufia M. Uddin, Constructing Bangladesh: Religion, Ethnicity, and Language in an Islamic Nation (Chapel Hill: University of North Carolina Press, 2006).

2 Seyfi Kenan, "III. Selim Dönemi Eğitim Anlayışında Arayışlar," Nizâm-ı Kadîm’den Nizâm-ı Cedìd'e III. Selim ve dönemi = Selim III and his Era from Ancien Régime to New Order, ed. Seyfi Kenan (İstanbul : Türkiye Diyanet Vakfı İslâm Araştırmaları Merkezi, 20ıo), pp. I29-I63. 
scholar Mehmet Birgivi, was indeed printed in 1803 in a new facility established for the military engineering school. Wilson's second chapter considers the Ottoman intellectuals and statesmen who, seeing the failure of strict policies and the increasing demand and desire for affordable Qur'an copies (particularly among new bureaucratic classes and madrasa students), embarked on projects of printing the Qur'an. Eventually the state contracted Osman Zeki Bey's Matbaa-i Osmaniye as sole publisher of the Qur'an, and imposed a legal monopoly that was in force until the Constitutional Revolution of 1908. The printed copies were distributed primarily for use in the growing school system, but were also sent to various Ottoman provinces (from the Balkans to the Arabian peninsula) and other Muslim communities around the world (from Afghanistan to Indonesia). With this massive scale of distribution, the printed Qur'an became a key symbol and facilitator of Abdülhamid II's pan-Islamic campaign to secure a transnational Sunni loyalty and, in general, of Ottoman imperial modernity.

The third and fourth chapters situate Qur'anic translation amid century-long efforts to present Turkish a legitimate medium of Islamic intellectual production and exchange. Chapter three focuses on vernacular Qur'an commentaries published in the second half of the nineteenth century, such as İsmail Ferruh Efendi's Mevakib, Muallim Ömer Naci's Hülasatül-İhlas, and Kureyşizade Mehmed Fevzi's Tefsir-i Sureti'l-Vakıa among others. Wilson argues that intellectuals without ulama backgrounds came to be authors of this new commentary genre - compiling classical tafsir works, and rendering them into simplified Turkish. Reflecting the new authorship, this genre also helped cultivate a new reading public that was not restricted to traditional scholarly circles. Chapter four moves to the post-1908 developments, such as solidification of national identities, and growing worries about missionary activities and their negative portrayal of the Qur'an. Wilson shows that intra-Muslim debate around Qur'an translation became a site for voicing contested visions not simply of (Qur'anic) Arabic's place in non-Arab Muslims' religiosity, but also of how a unity among disparate Muslim communities might be achieved in an age of nationalism. Such 'pragmatic' concerns were also prevalent in Muslims' responses to Christian missionary discourses on the Qur'an. Missionaries saw in Qur'an translation an opportunity to expose the Bible's 'superiority,' believing the dissociation from stylistic eloquence would reveal the Qur'an's incompatibility with modern progress. Muslims responded to this with a mix of general skepticism towards translations and an urgency to defend the Qur'an and its 'proper' interpretation with new translations. Wilson convincingly 
demonstrates that nationalisms and missionary activities had contributed to the politicization of the translation question in this period, shifting the focus away from theological and linguistic aspects of the Qur'an's translatability.

Building on this legacy, the next three chapters focus on translation projects - some realized, some failed - in the 1920s and 1930s. Chapter five discusses the process through which Turkish parliament came to commission an official Qur'an translation in 1925. Wilson shows how the first commercial translations (Süleyman Tevfik's Kur'an-ı Kerim Tercümesi, Hüseyin Kazım Kadri's Nurü'l-Beyan, and Cemil Sait's Kur'an-ı Kerim Tercümesi, all published in 1924) failed to meet the expectations of both independent Muslim intellectuals, and scholars associated with the state's Religious Affairs Directorate. This broad dissatisfaction amplified calls for the state to sponsor a better translation undertaken by more qualified writers. Wilson also highlights the particularity of the Turkish context in this period: while the debate in Turkey focused on how religion and national identity could accommodate one another, the wider Muslim community was considering translations as way of spreading Islam globally, defending Islam against Western secularists' critiques, and competing with Protestant missionaries' distribution of Bible translations. Chapter six details how the scholars of $A l-A z h a r$, the rising center of Islamic learning in the post-Caliphate period, came to support the printing of an English translation (Yusuf Ali's The Holy Qur'an) with these very goals in mind. In chapter seven, Wilson shifts back to Turkey, and demonstrates that Republican elites' plans to authorize the liturgical use of the Turkish translation alienated not only Mehmed Akif, the writer commissioned for the translation project, but also an overwhelming majority of Muslim citizens. Wilson's final chapter reflects on contemporary Muslims' enthusiastic efforts to print and disseminate mushaf and translations all around the world - which, according to Wilson, heralds "a new age of Qur'anic accessibility and ubiquity" (p. 258).

Given the scope of Wilson's research, this brief portrayal does not do full justice to his Translating the Qur'an; readers would find many compelling details in each chapter and appreciate the intellectual rigor and depth of Wilson's analysis. In the rest of this review, I will discuss some of the broader questions Wilson's research has raised concerning the politics and ethics of printing and translation, the idea of reform, and changing understandings of religious language, beginning with Wilson's discussion of early Republican sponsorship of the Qur'an translation. While much has been written on this translation project and state elites' 
eventual plans to authorize this translation for liturgical use, ${ }^{3}$ Wilson manages to provide a fresh perspective. This project has often been seen, by both secularists and their critics, as Mustafa Kemal's brainchild. Wilson demonstrates, however, that an 'ethos of vernacular access' to the Qur'an had been part of the Ottoman intellectual landscape since the nineteenth century, with the need for Qur'an translations becoming more vocally asserted in the post-1908 period. Wilson further argues that the commissioning of a translation in 1925 owed much to the public consensus among Muslim intellectuals (most of whom would disagree with later projects of vernacularizing liturgical language) that the state should step up and form a commission to translate authoritative sources of Islamic tradition. This crucial point highlights that what was at stake in early Republican reforms was not the 'ethos of vernacular access,' which most intellectuals and scholars seem to have shared, but rather the 'proper' form and space of the vernacular in Muslim religiosity.

The 'age of nationalism' has entailed not only the replacement of ecumenical languages (e.g. Church Latin or Qur'anic Arabic) with vernaculars, but also the emergence of modern ways of thinking about language and community. Benedict Anderson, for instance, highlights that while ecumenical languages are considered part of hierarchical religious cosmologies, in modernity languages have become relative to the community of their speakers. ${ }^{4}$ Unlike modern conceptions of language that presuppose the arbitrariness of the sign, ecumenical languages do not separate the word and the world, as its signs are considered intrinsic to the 'divine truth' they made apprehensible. Anderson argues that this is a main reason for Muslims' traditional discourses of the Qur'an untranslatability. As Wilson shows, however, not all saw the 'sanctity' of Qur'anic Arabic as an obstacle for translation. Musa Carullah Bigiyev, for example, thought that this view of linguistic sanctity preserved not only the text as it was revealed, but also fixed the original meanings in the text. As such, Bigiyev argued that translation is possible and permissible so long as it communicates the meanings fixed in the language of the revelation.

3 E.g. Dücane Cündioğlu, Türkçe Kur'an ve Cumhuriyet İdeolojisi (İstanbul: Kitabevi, 1998); Hidayet Aydar and Necmettin Gökkir, "Discussions on the Language of Prayer in Turkey: A Modern Version of the Classical Debate," Turkish Studies 8 (2007), pp. I2I-36; Umut Azak, Islam and Secularism in Turkey: Kemalism, Religion, and the Nation State (New York: I. B. Tauris, 2010); Amit Bein, Ottoman Ulema, Turkish Republic: Agents of Change and Guardians of Tradition (Stanford: Stanford University Press, 20II).

4 Benedict Anderson, Imagined Communities: Reflections on the Origin and Spread of Nationalism (London: Verso, 199I). 
Yet, as Wilson's research suggests, the modern view of languages as properties of particular communities has circulated far beyond nationalists. For instance, Arab Muslim intellectuals who opposed Qur'an translation, such as Rashid Rida, emphasized less the 'non-arbitrary' character of Arabic as scriptural language than the 'pragmatic function' of having a language shared by all Muslims. While these Arab Muslim intellectuals were promoting an Islamic cosmopolitanism against nationalists, who, in their view, would further fragmentation within the global Muslim community, they presented the commonality of Arabic among Muslims as a justification for Arabs' assumed leadership in a possible post-Caliphate unity.

Media technologies have been a fruitful arena for studies of political and aesthetic sensibilities in emerging Muslim publics. ${ }^{5}$ Wilson, too, shows that mass reproduction of the Qur'an, combined with increasing literacy, helped cultivate a new relationship to the Qur'an, reflected in an aspiration for direct engagement and understanding of the text. While the printing press made reproducing the Qur'an cheaper and faster, and also prevented mistakes that were common in scribal copies, Wilson suggests that the emergence of print culture was not just a technologically determined transformation, but a conjoining of traditional discourse with technological change. For instance, in laying out the debate around Namık Kemal's plan to import printed copies from England in the 1870s, Wilson highlights that both Kemal and his opponents, such as Ali Suavi, were concerned with the "ritual purity" of the printed Qur'an copies, asking questions such as: Would swine fat be used in the ink? By whom and in what conditions would the Qur'an copies be printed and transported? Where would they be stored? Such concerns had been present, but more or less managed in scribal culture, wherein the 'production' of texts was not detached from the community of users. Scribes and copyists acquired their reliability through different relations of authority, including genealogical chains linking masters and disciples. Although print technology obliterated the importance of such relationships, it brought questions about materiality and 'authenticity' into a new light, and sometimes even intensified these concerns.

Print-mediated publics are often associated with horizontal restructuring of religious authority, and less attention is paid to how their promise of egalitarianism

5 E.g. Dale F. Eickelman and Jon W. Anderson (eds.), New Media in the Muslim World: The Emerging Public Sphere, 2nd ed. (Bloomington: Indiana University Press, 2003); Charles Hirschkind, The Ethical Soundscape: Cassette Sermons and Islamic Counterpublics (New York: Columbia University Press, 2006). 
and accessibility also produce new worries concerning the control and regulation of religious knowledge. Wilson highlights this well in his discussion of public responses to the 1924 'commercial' Qur'an translations. Translators presented themselves as serving the "best interests of the people" (p.161), by rendering the Qur'an in the vernacular for a broader audience. For critics, however, the scale of dissemination had made 'flawed' translations and interpretations more dangerous, potentially leading lay citizens astray. One common source of worry was, of course, the quality of scholarly knowledge, as it was often intellectuals without traditional educational backgrounds who embarked on such translation projects. Yet translators were scrutinized not only for their technical expertise, but also for their "moral rectitude" (p.163). This popular expectation of the co-presence of knowledge and piety was indeed a main reason behind the overwhelming support for Mehmed Akif's commissioning for the state's translation project in 1925. Akif himself extended this idea of moral responsibility to his translation, hiding his completed portions when he became worried his translation might be used in new reform projects aiming to vernacularize liturgical language. This suggests that Qur'an translation brings together two different ways of thinking about the translator (at least among Muslims). First, the sanctity of the original Arabic text requires the translator do nothing more than 'carrying over' the intended meanings to target language, limiting the 'visibility' of the translator in the translated text. ${ }^{6}$ At the same time, however, in the reception and evaluation of translated text, the translator becomes especially and necessarily 'visible' in order for her piety and theological views to be scrutinized (standards of which, of course, change from one community to another).

In the Ottoman-Turkish context, as well as in other non-Arabic speaking Muslim contexts, translation debates have often been entangled with notions of religious reform: as a form of reinterpretation, translation can shed new light on previous understandings of concepts or categories, such that meanings attached to certain words may be replaced with 'better' ones, or neglected meanings brought forth for consideration. This relation between translation and reconsideration is quite prevalent in contemporary Turkey. Indeed, translating the Qur'an has preoccupied many intellectuals (from Süleyman Ateş to Ali Bulaç or Mustafa İslamoğlu) who are critical of certain aspects of traditional views. This function of translation is not novel to modernity and has been a common source of religious renewal through the ages. In the early twentieth century, however, as

6 Cf. Lawrence Venuti, The Translator's Invisibility (New York: Routledge, 1995). 
Wilson highlights, Qur'an translation was often associated with renewal in a very particular sense - that is, the framework of the Reformation and eventual vernacularization of Bible. Rather than questioning whether the Ottoman-Turkish advocacy of Qur'anic translatability can be described as 'Islamic Reformation,' Wilson considers how the Protestant Reformation as a historical model helped articulate a vision of a future Muslim community. His discussion suggests that the Reformation mattered less as a particular Christian movement or 'event' in Christianity, than in terms of its appeal as a central component of modernity's historical narrative - that is, a 'universal history' that has enabled comparison and evaluation of one's own society (or religious community) vis-à-vis its relative 'location' in progressing time. This narrative has also emphasized a radical conception of agency in historical change, while the Reformation originally had a rather strong eschatological sense of time. Luther was, for instance, expecting "the End of the World [that] was approaching with greater speed."7 In subsequent centuries, however, the Reformation has come to signify the beginning of the social and cultural progress that put Christian European societies ahead of others. With the help of this retrospective appropriation, modernist Muslims approached Qur'an translation and the idea of reform, far from Luther's apocalyptic tone, as way of actively bringing the 'hopeful' future closer.

All in all, Wilson's Translating the Qur'an is a rich book offering vivid accounts of Muslims' engagement with the Qur'an in modern times. It is a major accomplishment that provides a compelling perspective on how the theological, literary, social and economic aspects of Qur'an translation come into play in modernity. Wilson also offers a wide array of suggestions for further research and thinking, demonstrating that the question of translation offers unique and important tools for thinking about local and translocal manifestations of Islam in global world.

7 Reinhart Koselleck, Futures Past: On the Semantics of Historical Time (Cambridge: MIT Press, I985), p. I2. 